ISSN $=1980-993 X-$ doi:10.4136/1980-993X
www.agro.unitau.br/ambi-agua
E-mail: ambi-agua@@agro.unitau.br
Phone: +55 (12) 3625-4212

\title{
Editorial of the nineteenth edition of Ambiente \& Água - An Interdisciplinary Journal of Applied Science
}

\author{
(http://dx.doi.org/10.4136/ambi-agua.952)
}

\author{
Getulio Teixeira Batista \\ Professor of the Master Degree Program in Environmental Sciences of the University of Taubaté \\ e-mail: ambi-agua@agro.unitau.br
}

\begin{abstract}
We are publishing the nineteenth edition since the first issue published in August, 2006. Since then, all issues were published on time as schedule in December 31, April 30 and August 31 of every year. Hopefully, this encourages potential authors to submit their manuscripts to our journal. This $19^{\text {th }}$ edition contains 20 articles that were peer reviewed and selected for publication among 126 submitted in this period. The last three issues had also 20 articles published. These numbers meet one of the SciELO's criteria to consider the indexation of a journal. We continue to practice the complete open access policy and fostering the visibility, securing data storage, and working to increase the scientific impact of the journal.
\end{abstract}

Keywords: Ambi-Agua, environment, water resources, Google Analytics, Redalyc, Sumários.org.

\section{Editorial da décima nona edição da revista Ambiente \& Água - An Interdisciplinary Journal of Applied Science}

\section{RESUMO}

Estamos publicando a décima nona edição desde a primeira edição publicada em agosto de 2006. Desde então, todos os números foram publicados em dia conforme a programação: 31 de dezembro, 30 de abril e 31 de agosto de cada ano. Esperamos que esse fato encoraje potenciais autores submeterem seus trabalhos à nossa revista. Esta $19^{\text {a }}$ edição contém 20 artigos que foram revisados e selecionados para publicação entre 126 submetidos neste período. As últimas três edições também tiveram 20 artigos publicados. Esses números satisfazem um dos critérios da SciELO para uma revista ser considerada para indexação. Continuamos a praticar a política de acesso aberto completo e a promover a visibilidade, garantir diversos meios de armazenamento dos artigos publicados, e a trabalhar para aumentar o impacto científico da revista.

Palavras-chave: Ambi-Agua; meio ambiente; recursos hídricos, Google Analytics, Redalyc, Sumários.org.

\section{INTRODUCTION}

We continue to monitor the access and download of articles. Figure 1 shows the number of visits that the journal site had this year of 2012 up to August 18. One can observe that the accesses are pretty much constant, except just after an issue publication as can been seen in 
May and that they decrease during weekends. It is worth mentioning that we had access every single day and that the site was up during the entire period.

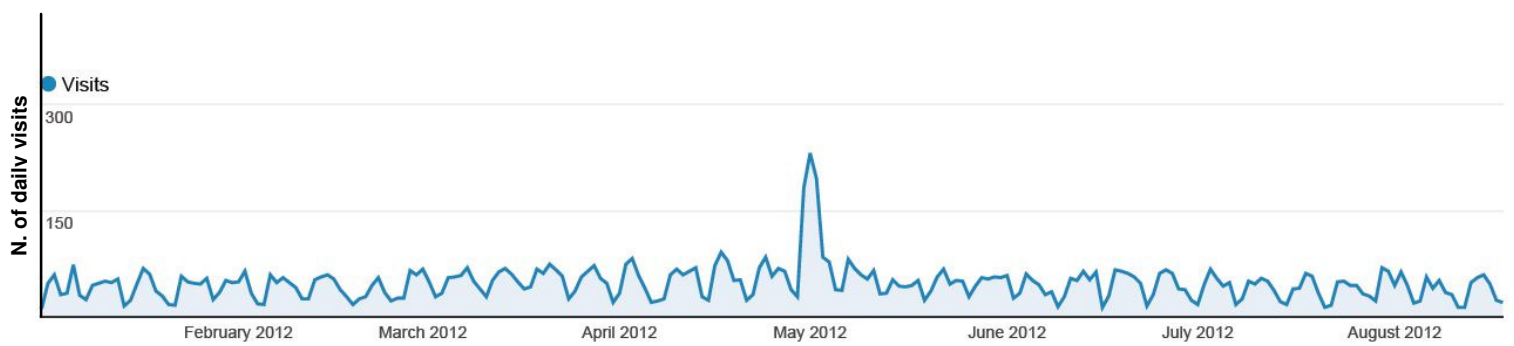

Figure 1. A total of 6,381 people visited Ambiente \& Agua Journal site from January 1st, 2012 to August $18^{\text {th }}, 2012$, completing 10,927 visits in this period and $74.6 \%$ of these visits have come from Brazil, 3.2\% from Mexico, 2.4\% from USA, 2.4\% from India, and 1.2\% from the United Kingdom, the remaining $16.2 \%$ from 112 other countries.

Source: Google Analytics (2012). <https://www.google.com/analytics >. Access August 18, 2012.

To guarantee data preservation, in addition to register the doi ${ }^{\mathrm{TM}}$ of all published articles, we made agreements with several other data basis to capture metadata and to store articles' full texts. In this issue, we show that Ambiente \& Agua articles are also stored in Redalyc and Sumários.org server (Figures 2 and 3) and they can be downloaded directly from their data basis.

Note that since Redalyc began to support Ambiente \& Agua Journal the number of downloads increased with a decrease in 2011. This drop coincided with the Natural and Social Sciences decrease in the number of downloads for that period.

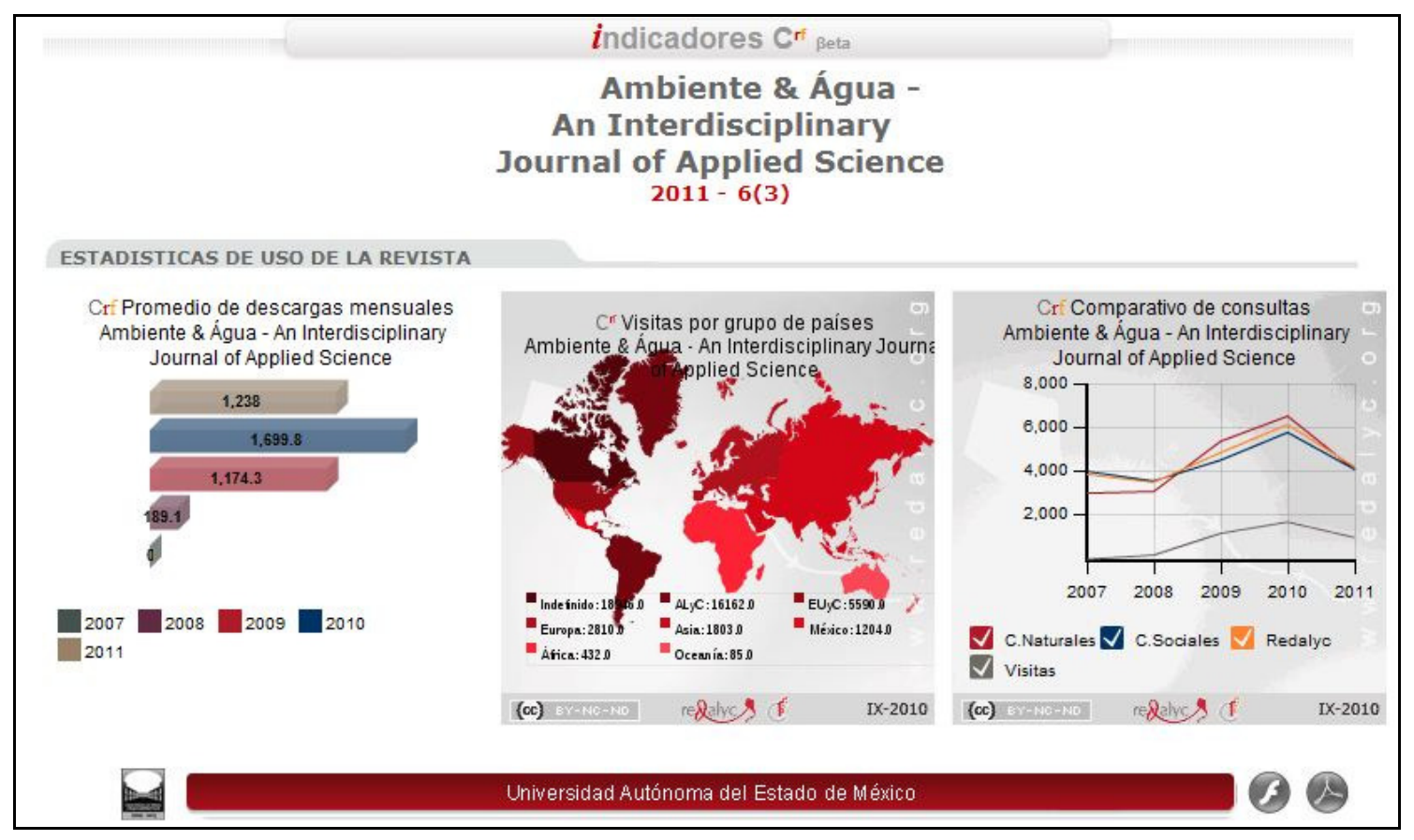

Figure 2. Page extracted from the Redalyc site that shows the number of yearly downloads of articles from their server.

Source: Red de Revistas Científicas de América Latina y el Caribe, España y Portugal Sistema de Información Científica (Redalyc). http://redalyc.uaemex.mx/src/inicio/HomRevRed.jsp?iCveEntRev=928. Acess August 20th, 2012). 
Figure 3 shows that all volumes and issues can also be accessed from the Sumários.org site.

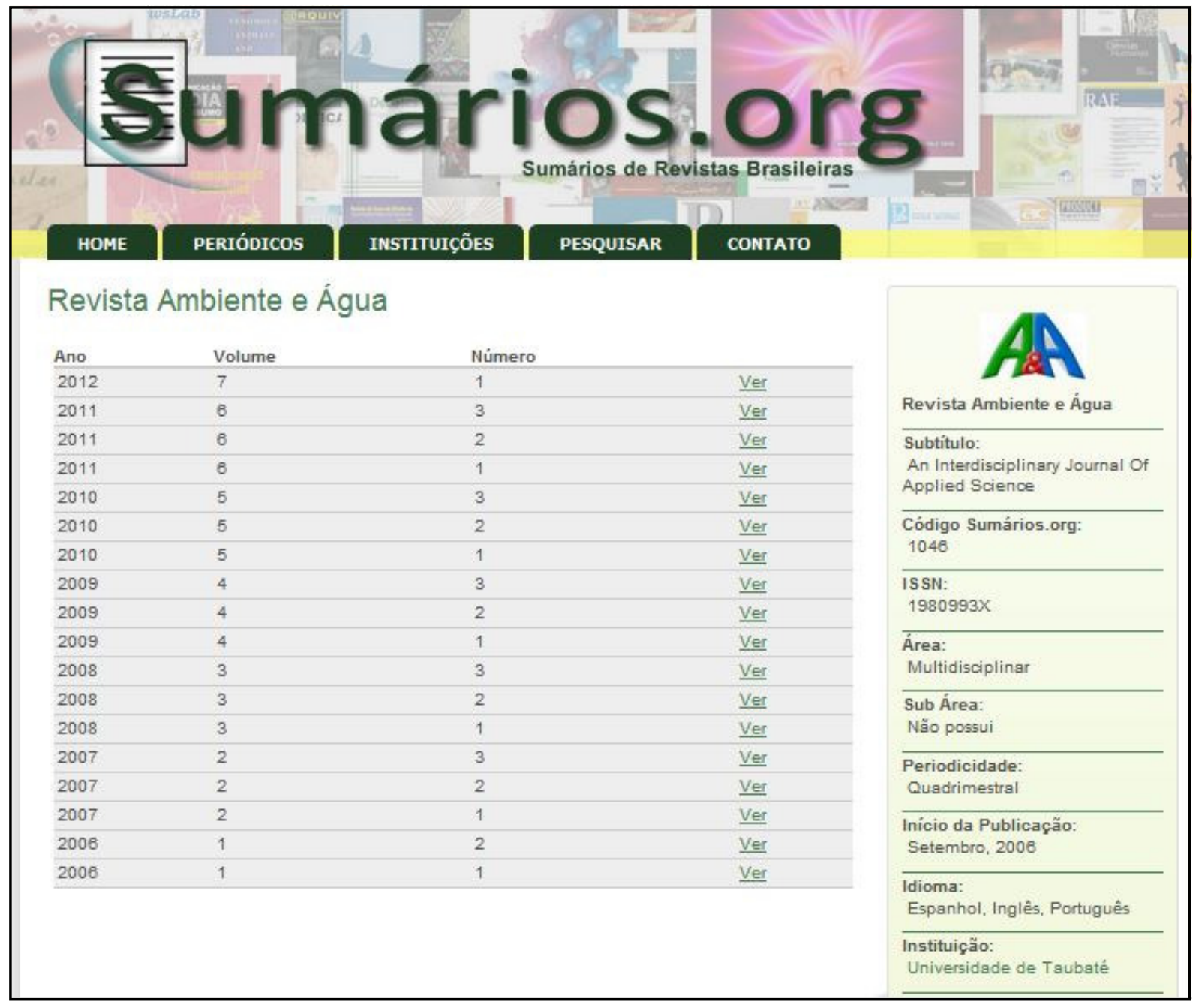

Figure 3. Page extracted from Sumários.org site the published issues of Ambiente \& Agua that can be downloaded directly from their server.

Source: Sumários de Revistas Brasileiras (Sumários.org): http://sumarios.org/revistas/revista-ambiente-e\%C3\%A1gua-interdisciplinary-journal-applied-science. Acess August 20, 2012).

\section{FINAL REMARKS}

Ambi-Agua welcomes good quality submissions that effectively increases the scientific knowledge in the great interdisciplinary scientific thematic area related to Environmental Sciences and Water Resources. Thematic areas include Hydrology, Hydrogeology, Environmental and Sanitation Engineering, Forest Engineering and Forest Resources, Ecology, Aqüiculture, Oceanology and Fishing Resources, Agronomy, Agrometeorology and Agricultural Engineering, Global Change, Fishing Engineering, Environmental Zootechny, Geography and Geology, as well as Remote Sensing, Geoinformation, and Spatial Analysis However, these broad areas have to focus on water or environmental sciences issues for the submission be considered.

Ambi-Agua continues with the complete Open Access Policy: no fee to publish and no fee to access articles and is committed to register doi ${ }^{\mathrm{TM}}$ for all published articles. 